\title{
Macronutrient uptake and export in transgenic corn under two levels of fertilization
}

\author{
Carine Gregório Machado Silva( ${ }^{(1)}$, Álvaro Vilela de Resende(2), Aarón Martínez Gutiérrez ${ }^{(3)}$, \\ Silvino Guimarães Moreira ${ }^{(1)}$, Emerson Borghi ${ }^{(2)}$ and Gabriela Oliveira Almeida ${ }^{(3)}$
}

\begin{abstract}
(1)Universidade Federal de Lavras, Departamento de Agricultura, Campus Universitário, Caixa Postal 3037, CEP 37200-000 Lavras, MG, Brazil. E-mail: carine.greg@gmail.com, silvino@ufsj.edu.br (2)Embrapa Milho e Sorgo, Rodovia MG-424, Km 45, Caixa Postal 285, CEP 35701-970 Sete Lagoas, MG, Brazil. E-mail: alvaro.resende@embrapa.br, emerson.borghi@embrapa.br (3)Universidade Federal de São João del-Rei, Campus Sete Lagoas, Rodovia MG 424, Km 47, Caixa Postal 56, CEP 35701-970 São João del-Rei, MG, Brazil. E-mail: aaron_0715@hotmail.com, gabrielaolivalm@gmail.com
\end{abstract}

\begin{abstract}
The objective of this work was to evaluate macronutrient uptake and export by transgenic corn hybrids under medium and high fertilization levels. For each fertilization level, a randomized complete block design was carried out in the summer crop season, under no-tillage and supplementary irrigation, with four cultivars and four replicates. Plants were sampled throughout the entire cycle and separated into leaves, stalk, husk, cob, and grains for the determination of dry matter mass and accumulation of macronutrients in the different growth stages. Under the high fertilization level, a greater dry matter mass and nutrient uptake were observed, but grain yield was similar to that under the medium fertilization level. The uptake of $\mathrm{N}, \mathrm{P}, \mathrm{Ca}$, $\mathrm{Mg}$, and $\mathrm{S}$ occurs until later in the cycle of the transgenic cultivars, which also showed lower concentrations of $\mathrm{P}, \mathrm{K}$, and $\mathrm{S}$ in grains, when compared to older hybrids. The differential behavior of the evaluated cultivars under different fertilization levels indicates the need of updating and improving nutritional management and fertilizer recommendations for the corn crop.
\end{abstract}

Index terms: Zea mays, fertilizer use efficiency, high productivity, luxury consumption, nutrient absorption, nutritional requirement.

\section{Absorção e exportação de macronutrientes em milho transgênico sob dois níveis de fertilização}

Resumo - O objetivo deste trabalho foi avaliar a absorção e a exportação de macronutrientes por híbridos transgênicos de milho sob níveis de fertilização médio e alto. Em cada nível de adubação, utilizou-se delineamento de blocos ao acaso na safra de verão, sob plantio direto e irrigação suplementar, com quatro cultivares e quatro repetições. As plantas foram amostradas ao longo de todo o ciclo, tendo-se separado folhas, colmo, palha da espiga, sabugo e grãos para determinação de massa de matéria seca e acúmulo de macronutrientes nos diferentes estádios fenológicos. Sob o nível elevado de fertilização, observou-se maior produção de massa de matéria seca e extração de nutrientes, mas produtividade de grãos similar à sob o nível médio de fertilização. Parte da absorção de $\mathrm{N}, \mathrm{P}, \mathrm{Ca}, \mathrm{Mg}$ e $\mathrm{S}$ ocorre mais tarde no ciclo das cultivares transgênicas, as quais também apresentaram menores concentrações de $\mathrm{P}, \mathrm{K}$ e $\mathrm{S}$ nos grãos quando comparadas a híbridos mais antigos. O comportamento diferencial das cultivares avaliadas sob diferentes níveis de fertilização indica a necessidade de atualização e aprimoramento das recomendações de manejo nutricional e de adubação para a cultura do milho.

Termos para indexação: Zea mays, eficiência de uso de fertilizantes, alta produtividade, consumo de luxo, extração de nutrientes, exigência nutricional.

\section{Introduction}

Knowledge of nutrient uptake and export rates throughout the corn (Zea mays L.) cycle is necessary to determine fertilization level and timing, as well as the minimum quantity required to maintain soil fertility (Duarte et al., 2003; Von Pinho et al., 2009). Plant nutritional balance and a properly managed soil nutrient supply maximize the expression of the productive potential of cultivars, besides reducing losses in the cropping system.

The general patterns of nutrient requirement for corn growth in Brazil were established through a series of research studies, mostly conducted more than two decades ago (Furlani et al., 1977; Vasconcellos et al., 1983; Coelho \& França, 1995). Moreover, 
many of the data on corn nutrition are derived from experiments carried out under conventional tillage and with old cultivars, no longer in the market. Therefore, most of the information available in official fertilizer recommendation tables (Raij et al., 1997; Alves et al., 1999; Sousa \& Lobato, 2004) is not updated considering the higher productivity levels of the current cropping systems, which also involve crop diversification and no-tillage. These updates are long overdue since crop nutritional requirements differ according to yield and cultivars (Von Pinho et al., 2009; Bender et al., 2013). In this context, transgenic corn hybrids have shown increased productive potential (Freitas et al., 2013; Padilha et al., 2015).

The objective of this work was to evaluate macronutrient uptake and export by transgenic corn hybrids under medium and high fertilization levels.

\section{Materials and Methods}

The study was conducted in a Latossolo Vermelho (Santos et al., 2013), i.e., a very clayey dystrophic Oxisol, during the 2014/2015 summer crop season, at Embrapa Milho e Sorgo, in the municipality of Sete Lagoas, in the state of Minas Gerais, Brazil (19² $28^{\prime} 30^{\prime \prime} \mathrm{S}, 44^{\circ} 15^{\prime} 08^{\prime \prime} \mathrm{W}$, at $732 \mathrm{~m}$ altitude).

The experimental area had been used under notillage for seven years, mainly with soybean [Glycine $\max$ (L.) Merr.] and corn crops. In 2012, the area was divided into two conditioned environments, which have been maintained with differentiated investment levels: medium and high fertilization (Silva, 2016). Bean (Phaseolus vulgaris L.) was grown in the off-season of 2014. In November, prior to the installation of the experiment, a corrective fertilization with $2.0 \mathrm{Mg} \mathrm{ha}^{-1}$ dolomitic limestone $(80 \%$ effective calcium carbonate equivalent), $1.0 \mathrm{Mg} \mathrm{ha}^{-1}$ phosphogypsum, and $200 \mathrm{~kg}$ ha $^{-1}$ of a 3:1 mixture of potassium chloride and FTE BR 12 (Nutriplant Indústria e Comércio S/A, Barueri, SP, Brazil) were broadcast in the high investment environment, aiming at maintaining the highest soil fertility condition. The medium investment area did not receive this fertilization.

The study consisted of the cultivation of four transgenic corn hybrids - AG 8088PROX, DKB 310PRO2, DKB 390PRO, and P 30F53 YH - in environments with medium and high fertilization investment levels. For each environment, the experimental design was randomized complete blocks, with four replicates. The plots consisted of four $6.0-\mathrm{m}$ rows, spaced $0.5 \mathrm{~m}$ from each other. The useful area, where the plants were sampled to determine nutrient uptake throughout the cycle, were considered as the two center lines, leaving $1.0 \mathrm{~m}$ at the edges, as borders. For grain yield evaluation, the treatments were conducted in extra plots, in each block, totaling another 32 plots for the analysis of grain yield.

The seeds used in the high investment environment were treated with $350 \mathrm{~mL}$ of the insecticide imidacloprid $\left(150 \mathrm{~g} \mathrm{~L}^{-1}\right)+$ thiodicarb $\left(450 \mathrm{~g} \mathrm{~L}^{-1}\right)$ per $100 \mathrm{~kg}$ seeds, plus $600 \mathrm{~mL}$ of the fertilizer Biozyme (Arysta Lifescience, São Paulo, SP, Brazil) per 100 $\mathrm{kg}$ seeds, containing: $1.73 \% \mathrm{~N}, 5.0 \% \mathrm{~K}_{2} \mathrm{O}, 2.1 \% \mathrm{~S}$, $0.49 \% \mathrm{Fe}, 2.43 \% \mathrm{Zn}, 1.0 \% \mathrm{Mn}$, and $0.08 \% \mathrm{~B}$. In the medium investment environment, seeds received only the insecticide. Sowing was carried out on 12/17/2014, with 70,000 seeds per hectare.

A total of 340 and $500 \mathrm{~kg} \mathrm{ha}^{-1} \mathrm{~N}-\mathrm{P}_{2} \mathrm{O}_{5}-\mathrm{K}_{2} \mathrm{O}$, of the formula $08-28-16+0.3 \% \mathrm{~B}$, was used in the medium and high investment environments, respectively. The medium investment management was based on the recommendations of Sousa \& Lobato (2004) for obtaining grain yields between 8 and $10 \mathrm{Mg} \mathrm{ha}^{-1}$.

When plants reached the V4 growth stage, 20 days after sowing (DAS), soil was sampled at $0-20 \mathrm{~cm}$, in and in between the lines (Table 1). Topdressing fertilization with $90 \mathrm{~kg} \mathrm{ha}^{-1} \mathrm{~N}$ (200 kg ha-1 urea) was also applied at this stage. In the high investment environment, two additional topdressing fertilizations were performed: one with $70 \mathrm{~kg} \mathrm{ha}^{-1} \mathrm{~N}$ and $\mathrm{K}_{2} \mathrm{O}\left(350 \mathrm{~kg} \mathrm{ha}^{-1} \mathrm{~N}^{-\mathrm{P}_{2} \mathrm{O}_{5^{-}}}\right.$ $\mathrm{K}_{2} \mathrm{O}$ 20-00-20), at 27 DAS, in the V5 growth stage; and the other with $40 \mathrm{~kg} \mathrm{ha}^{-1} \mathrm{~N}$ plus $44 \mathrm{~kg} \mathrm{ha}^{-1} \mathrm{~S}(200$ $\mathrm{kg} \mathrm{ha}^{-1}$ ammonium sulfate), at $33 \mathrm{DAS}$, in the V7 stage. Finally, in the V7 stage, in the high investment environment, leaves were fertilized with a mixture of $2.0 \mathrm{~L} \mathrm{ha}^{-1}$ Biozyme fertilizer (Arysta Lifescience, São Paulo, SP, Brazil), $2.5 \mathrm{~kg} \mathrm{ha}^{-1}$ monoammonium phosphate, and $1.5 \mathrm{~kg} \mathrm{ha}^{-1}$ calcium nitrate.

Weed control was performed by desiccation with glyphosate before sowing, and also by the application of the herbicides tembotrione and atrazine at the V4 stage. Caterpillar control in hybrids with different transgenic events was done with the insecticides lufenuron and flubendiamide, applied in the V5 and V6 stages, respectively. Since no crop disease was observed, fungicides were not applied in any of the areas. 
Seasonal nutrient uptake was estimated with samples taken during the cycle, in two representative plants inside the useful area, at ten growth stages, according to Ritchie et al. (2003): V4, V5, V7, V9, V12, VT (tasseling), R1 (full flowering), R2, R5, and R6 (physiological maturation). These stages corresponded to $20,26,33,40,49,57,64,71,104$, and 131 DAS, respectively. Samplings were carried out when the plots had more than $50 \%$ of the plants in each of those growth stages. At each new sampling, the first remaining plant was skipped in the useful area, representing an internal border. Plants were cut $3.0 \mathrm{~cm}$ above the soil, and leaves, stalk, husk cob, and grains were separated, according to the growth stages. The samples were oven-dried at $65^{\circ} \mathrm{C}$ and weighed; dry matter was crushed using a knife mill, placed inside plastic containers, and sent to a laboratory for the determination of $\mathrm{N}, \mathrm{P}, \mathrm{K}, \mathrm{Ca}, \mathrm{Mg}$, and $\mathrm{S}$ contents, as described by Silva (2009).

Nutrient accumulation was calculated for each sampled part of the plants. Grain yield was evaluated after physiological maturation, by collecting the cobs in $4.0 \mathrm{~m}$ of the two central lines inside the extra plots,

Table 1. Soil chemical analysis in medium and high fertilization environments, at the V4 stage, 20 days after corn (Zea mays) sowing.

\begin{tabular}{lcc}
\hline Soil properties & \multicolumn{2}{c}{ Fertilization level } \\
\cline { 2 - 3 } & Medium & High \\
\hline $\mathrm{pH}\left(\mathrm{H}_{2} \mathrm{O}\right)$ & 6.1 & 6.0 \\
$\mathrm{OM}\left(\mathrm{dag} \mathrm{kg}^{-1}\right)$ & 4.1 & 3.9 \\
$\mathrm{P}^{(1)}\left(\mathrm{mg} \mathrm{dm}^{-3}\right)$ & 14 & 22 \\
$\mathrm{~K}\left(\mathrm{mg} \mathrm{dm}^{-3}\right)$ & 54 & 159 \\
$\mathrm{~S}^{(2)}\left(\mathrm{mg} \mathrm{dm}^{-3}\right)$ & 4 & 15 \\
$\mathrm{Ca}\left(\mathrm{cmol}_{\mathrm{c}} \mathrm{dm}^{-3}\right)$ & 6.2 & 5.7 \\
$\mathrm{Mg}\left(\mathrm{cmol}_{\mathrm{c}} \mathrm{dm}^{-3}\right)$ & 1.0 & 1.2 \\
$\mathrm{Al}{ }^{1+}\left(\mathrm{cmol}_{\mathrm{c}} \mathrm{dm}^{-3}\right)$ & 0 & 0 \\
$\mathrm{H}+\mathrm{AL}\left(\mathrm{cmol}_{\mathrm{c}} \mathrm{dm}^{-3}\right)$ & 5.6 & 6.8 \\
$\mathrm{CEC}\left(\mathrm{cmol}_{\mathrm{c}} \mathrm{dm}^{-3}\right)$ & 13 & 14 \\
$\mathrm{Base} \mathrm{saturation}(\mathrm{BS}, \%)$ & 57 & 52 \\
$\mathrm{Al}$ saturation $(\mathrm{m}, \%)$ & 0 & 0 \\
\hline
\end{tabular}

(1)Mehlich-1. ${ }^{(2)} \mathrm{S}$ in the 20-40-cm layer: 10 and $21 \mathrm{mg} \mathrm{dm}^{-3}$ in the medium and high fertilization environments, respectively. Levels of micronutrients $\left(\mathrm{mg} \mathrm{dm}^{-3}\right)$ were: $1.1 \mathrm{~B}, 0.9 \mathrm{Cu}, 28 \mathrm{Fe}, 54 \mathrm{Mn}$, and $3.4 \mathrm{Zn}$ in the medium fertilization environment; and $1.8 \mathrm{~B}, 0.5 \mathrm{Cu}, 19 \mathrm{Fe}, 9.2 \mathrm{Mn}$, and $3.8 \mathrm{Zn}$ in the high fertilization one. Texture analysis showed: $130 \mathrm{~g}$ $\mathrm{kg}^{-1}$ sand, $210 \mathrm{~g} \mathrm{~kg}^{-1}$ silt, and $660 \mathrm{~g} \mathrm{~kg}^{-1}$ clay. OM, organic matter; CEC, cation exchange capacity. which were used solely for this purpose. Grain yield was corrected for $13 \%$ moisture content, and the accumulation of nutrients in grains was also estimated.

The joint analysis of variance was used, and means were grouped according to the Scott-Knott test, with the Sisvar software (Ferreira, 2011).

\section{Results and Discussion}

The total dry matter yield (TDM) of the plant shoot differed according to the fertilization investment level in the V5, R2, and R6 stages, with increased TDM in the high investment environment. In the V5 stage, TDM was $977.0 \mathrm{~kg} \mathrm{ha}^{-1}$ with high investment and $837.0 \mathrm{~kg} \mathrm{ha} \mathrm{h}^{-1}$ with medium investment; in R2, 16,766 and 14,371, respectively; and in R6, 27,095 and 24,159 $\mathrm{kg} \mathrm{ha}^{-1}$. These TDM values exceeded the range from 10,950 to $18,650 \mathrm{~kg} \mathrm{ha}^{-1}$ obtained in previous studies with conventional corn in Brazil (Coelho \& França, 1995; Duarte et al., 2003), being close to the values from 21,649 to $24,707 \mathrm{~kg} \mathrm{ha}^{-1}$ reported more recently by Bender et al. (2013) for transgenic crops in the USA.

The increase in grain yield has historically accompanied the increase in dry matter production capacity (Bender et al., 2013); and this biomass accumulation potential is the induction force for nutrient uptake. However, the present work did not fully confirm this relationship, since grain yield was statistically the same between environments, although the high investment promoted greater TDM values. Conversely, the harvest index, which reflects the efficiency of dry matter conversion to grains, was lower in the high investment environment (0.42), compared with the medium investment one (0.45).

The hybrids differed significantly regarding the average grain yield obtained in the two environments, in the following decreasing order: DKB 310PRO2, with 13,219 $\mathrm{kg} \mathrm{ha}^{-1}$; DKB 390PRO, with 10,793 $\mathrm{kg} \mathrm{ha}^{-1}$; AG 8088PROX, with 10,784 kg ha' ${ }^{-1}$; and P 30F53 YH, with $9,299 \mathrm{~kg} \mathrm{ha}^{-1}$.

The effect of crop environments on $\mathrm{N}$ uptake was significant in V5 and from the V12 stage to physiological maturation (Table 2). The greater accumulation of $\mathrm{N}$ in plants cultivated with the highest amount of nutrients was mainly due to topdressing fertilizations with $\mathrm{N}$, carried out in the environment with high investment level, in the V5 and V7 stages.

Pesq. agropec. bras., Brasília, v.53, n.12, p.1363-1372, Dec. 2018 DOI: $10.1590 /$ S0100-204X2018001200009 
Up to V9, the average percentage of $\mathrm{N}$ uptake, in relation to the total accumulated during the cycle, was $47 \%$ in the high investment environment, which was lower than the $57 \%$ in the medium investment. This reveals a later uptake capacity by cultivars when there is a more abundant nutrient supply. Von Pinho et al. (2009) reported small average accumulations of $40.6 \mathrm{~kg}$ $\mathrm{ha}^{-1} \mathrm{~N}$ in the initial development stages, with significant increases from $107.3 \mathrm{~kg} \mathrm{ha}^{-1}$ in V8 to $196.7 \mathrm{~kg} \mathrm{ha}^{-1}$ until the stages after flowering, between R1 and R2.

Up to tasseling, corn expressed an average of $73 \%$ maximum $\mathrm{N}$ uptake, corresponding to 180 and $246 \mathrm{~kg}$ $\mathrm{ha}^{-1}$, in the medium and high investment environments, respectively. In both cases, uptake increased up to the end of the cycle, reaching its maximum at physiological maturity (Table 2 and Figure 1). The quantity of $\mathrm{N}$ needed by corn varies according to the yield range of the crop (Fontoura \& Bayer, 2009). In the present study, higher yields would be expected in the environment with high fertilization, given the large quantity of $\mathrm{N}$ accumulated by plants. However, this did not occur, evidencing luxury consumption, which reinforces the need for economic evaluations to better adjust nutrient supply.

At the end of the cycle, in the two assessed environments, an average of $53 \% \mathrm{~N}$ contained in the plant was allocated to grains (Table 3 and Figure 1). This value is lower than the $64 \% \mathrm{~N}$ extracted by the crop according to Bender et al. (2013) and than the 65 and $75 \%$ total $\mathrm{N}$ according to classical Brazilian literature, such as the studies of Coelho \& França (1995) and Vasconcellos et al. (1998).

The export in grains was approximately $177 \mathrm{~kg} \mathrm{ha}^{-1}$ $\left(15.6 \mathrm{~kg} \mathrm{Mg}^{-1}\right)$ in the high investment environment and $134 \mathrm{~kg} \mathrm{ha}^{-1}\left(12.4 \mathrm{~kg} \mathrm{Mg}^{-1}\right)$ in the medium one. This is also evidence of the occurrence of luxury consumption in corn under the high fertilization investment. This result highlights the convenience of knowing the response potential of hybrids in each location and cultivation condition in order to obtain subsidies to optimize $\mathrm{N}$ fertilization, aiming at higher crop yields, greater nutrient and economic efficiency, and lower risks of environmental contamination.

Phosphorus uptake varied significantly between the environments, from V12 to R5, with greater differences observed in the reproductive stage - there was a $28 \%$ increase in uptake in the high fertilization investment, in R2 (Table 2). In both environments, until tasseling, the plants reached an average of $69 \%$ maximum $\mathrm{P}$ uptake (Figure 1), a process that continued up to the final development stages. The maximum accumulations were verified in R5 and R6, in the medium and high fertilization environments, respectively (Table 2 and Figure 1). Von Pinho et al. (2009) concluded that the greatest demand for P occurs precisely at the reproductive stages, with a peak in $P$ uptake at 125 days after emergence, in the R5 stage. This behavior is explained in part by the participation of $\mathrm{P}$ in compounds that transfer energy

Table 2. Equivalents of accumulation ${ }^{(1)}$ of $\mathrm{N}, \mathrm{P}_{2} \mathrm{O}_{5}, \mathrm{~K}_{2} \mathrm{O}, \mathrm{Ca}, \mathrm{Mg}$, and $\mathrm{S}$ during the corn (Zea mays) cycle, in medium and high fertilization environments in the municipality of Sete Lagoas, in the state of Minas Gerais, Brazil, in 2015(2).

\begin{tabular}{|c|c|c|c|c|c|c|c|c|c|c|c|c|}
\hline \multirow[t]{2}{*}{ Growth stage } & \multicolumn{2}{|c|}{$\mathrm{N}\left(\mathrm{kg} \mathrm{ha}^{-1}\right)$} & \multicolumn{2}{|c|}{$\mathrm{P}_{2} \mathrm{O}_{5}\left(\mathrm{~kg} \mathrm{ha}^{-1}\right)$} & \multicolumn{2}{|c|}{$\mathrm{K}_{2} \mathrm{O}\left(\mathrm{kg} \mathrm{ha}^{-1}\right)$} & \multicolumn{2}{|c|}{$\mathrm{Ca}\left(\mathrm{kg} \mathrm{ha}^{-1}\right)$} & \multicolumn{2}{|c|}{$\operatorname{Mg}\left(\mathrm{kg} \mathrm{ha}^{-1}\right)$} & \multicolumn{2}{|c|}{$\mathrm{S}\left(\mathrm{kg} \mathrm{ha}^{-1}\right)$} \\
\hline & Medium & High & Medium & High & Medium & High & Medium & High & Medium & High & Medium & High \\
\hline V4 & $10.9 \mathrm{a}$ & $12.4 \mathrm{a}$ & $5.8 \mathrm{a}$ & $3.2 \mathrm{a}$ & $24.7 \mathrm{a}$ & $15.4 \mathrm{~b}$ & $2.1 \mathrm{a}$ & $0.9 \mathrm{~b}$ & $1.6 \mathrm{~b}$ & $0.7 \mathrm{a}$ & $1.4 \mathrm{a}$ & $1.0 \mathrm{~b}$ \\
\hline V5 & $38.9 b$ & $47.8 \mathrm{a}$ & $8.8 \mathrm{a}$ & $10.1 \mathrm{a}$ & $39.0 \mathrm{~b}$ & $51.9 \mathrm{a}$ & $4.1 \mathrm{a}$ & $3.6 \mathrm{a}$ & $3.1 \mathrm{a}$ & $2.6 \mathrm{~b}$ & $2.4 \mathrm{~b}$ & $3.4 \mathrm{a}$ \\
\hline V7 & $93.6 \mathrm{a}$ & $105.1 \mathrm{a}$ & $18.1 \mathrm{a}$ & $20.1 \mathrm{a}$ & $81.8 \mathrm{~b}$ & $120.9 a$ & $12.4 \mathrm{a}$ & $10.8 b$ & $10.5 \mathrm{a}$ & $7.6 \mathrm{~b}$ & $5.0 \mathrm{~b}$ & $6.2 \mathrm{a}$ \\
\hline V9 & $140.6 \mathrm{a}$ & $158.7 \mathrm{a}$ & $25.4 \mathrm{a}$ & $25.9 \mathrm{a}$ & $127.4 b$ & $216.8 \mathrm{a}$ & $23.5 \mathrm{a}$ & $19.2 b$ & $20.6 \mathrm{a}$ & $14.1 b$ & $7.3 b$ & $8.4 \mathrm{a}$ \\
\hline V12 & $166.6 \mathrm{~b}$ & $231.2 \mathrm{a}$ & $34.9 b$ & $41.9 \mathrm{a}$ & $142.1 b$ & $312.5 \mathrm{a}$ & $32.6 \mathrm{a}$ & $31.3 \mathrm{a}$ & $29.8 \mathrm{a}$ & $24.9 b$ & $9.2 \mathrm{~b}$ & $12.6 \mathrm{a}$ \\
\hline VT & $180.4 b$ & $246.2 \mathrm{a}$ & $41.8 \mathrm{~b}$ & $47.3 \mathrm{a}$ & $174.9 \mathrm{~b}$ & $357.8 \mathrm{a}$ & $33.2 \mathrm{a}$ & $31.9 \mathrm{a}$ & $32.7 \mathrm{a}$ & $26.3 b$ & $11.1 \mathrm{~b}$ & $13.9 \mathrm{a}$ \\
\hline $\mathrm{R} 1$ & $199.6 b$ & $247.7 \mathrm{a}$ & $42.6 b$ & $47.4 \mathrm{a}$ & $146.4 b$ & $350.6 \mathrm{a}$ & $36.7 \mathrm{a}$ & $32.0 \mathrm{a}$ & $33.7 \mathrm{a}$ & $26.6 b$ & $12.4 b$ & $15.6 \mathrm{a}$ \\
\hline $\mathrm{R} 2$ & $211.7 \mathrm{~b}$ & $312.9 \mathrm{a}$ & $50.5 b$ & $64.7 \mathrm{a}$ & $147.2 \mathrm{~b}$ & $354.8 \mathrm{a}$ & $43.9 \mathrm{a}$ & $43.9 \mathrm{a}$ & $37.4 \mathrm{a}$ & $34.3 \mathrm{a}$ & $13.7 \mathrm{~b}$ & $19.2 \mathrm{a}$ \\
\hline R5 & $237.9 b$ & $323.2 \mathrm{a}$ & $60.3 b$ & $66.1 \mathrm{a}$ & $110.1 b$ & $256.6 \mathrm{a}$ & $57.8 \mathrm{a}$ & $55.8 \mathrm{a}$ & $41.4 \mathrm{a}$ & $39.9 a$ & $18.7 b$ & $22.6 \mathrm{a}$ \\
\hline R6 & $245.5 b$ & $337.7 \mathrm{a}$ & $59.2 \mathrm{a}$ & $67.9 \mathrm{a}$ & $109.5 b$ & $214.8 \mathrm{a}$ & $48.3 \mathrm{a}$ & $50.4 \mathrm{a}$ & $36.3 \mathrm{a}$ & $37.2 \mathrm{a}$ & $17.6 \mathrm{~b}$ & $22.9 \mathrm{a}$ \\
\hline
\end{tabular}

${ }^{(1)}$ Average of the four evaluated hybrids. ${ }^{(2)}$ Means followed by equal letters, in the rows, do not differ by the Scott-Knott test, at $5 \%$ probability. 
for the transformation of sugar into starch (Vilar \& Vilar, 2013).

The equivalent quantities of $\mathrm{P}_{2} \mathrm{O}_{5}$ decreased considerably in the vegetative parts and in the husk of the plant from R2 onwards, with 74 and $69 \%$ of the total allocated to grains in the medium and high investment
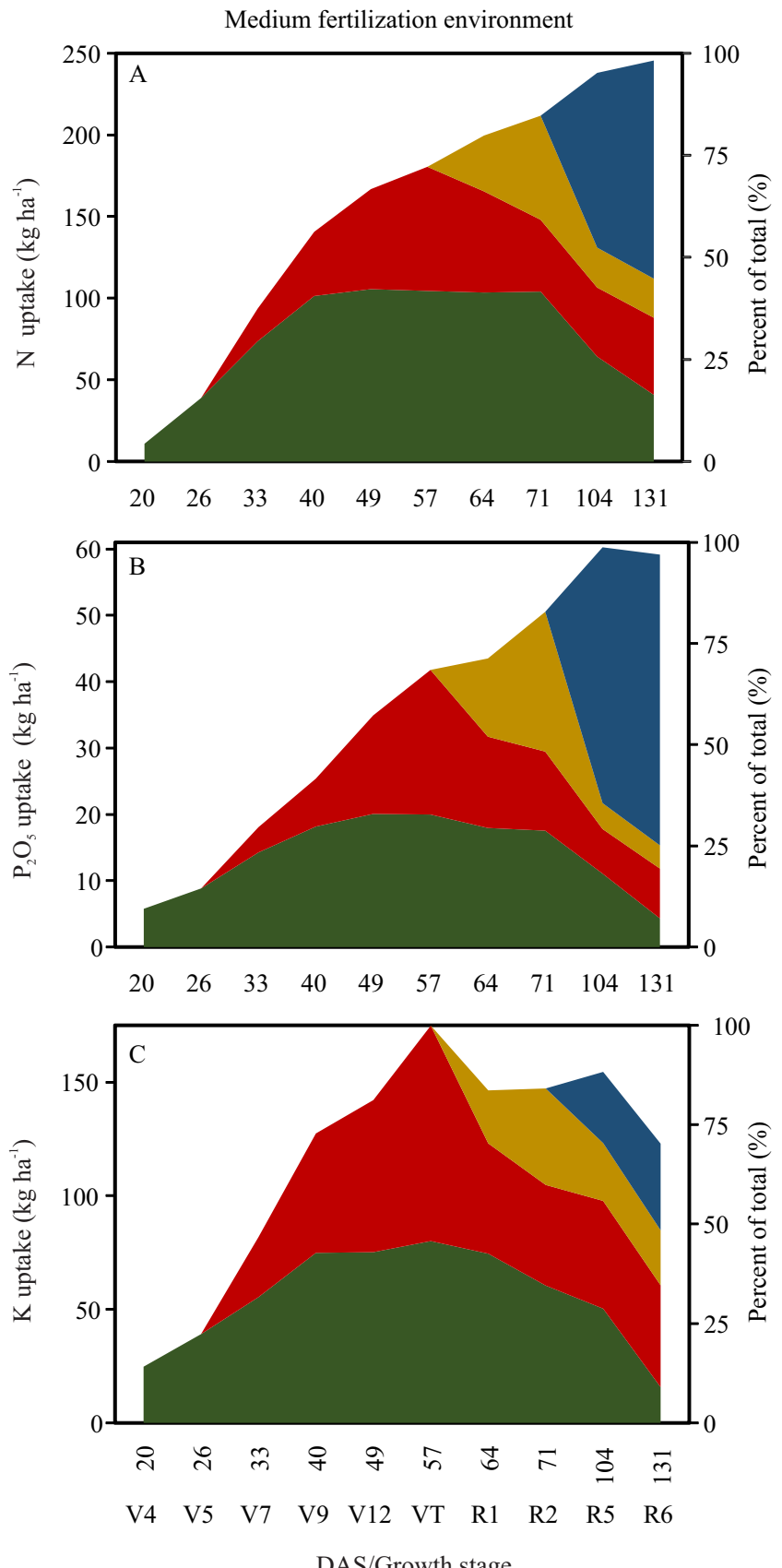

DAS/Growth stage

- Leaves $\quad$ Stalk and leaf sheaths $\quad$ Husk and cob

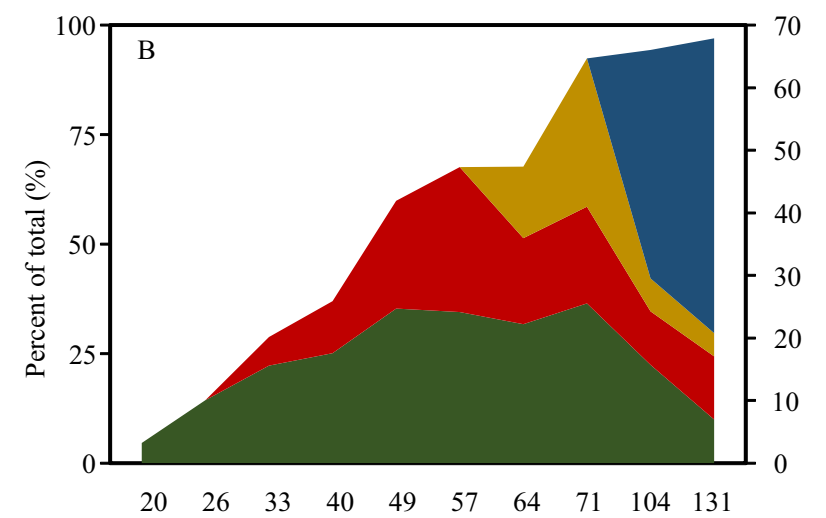

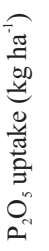

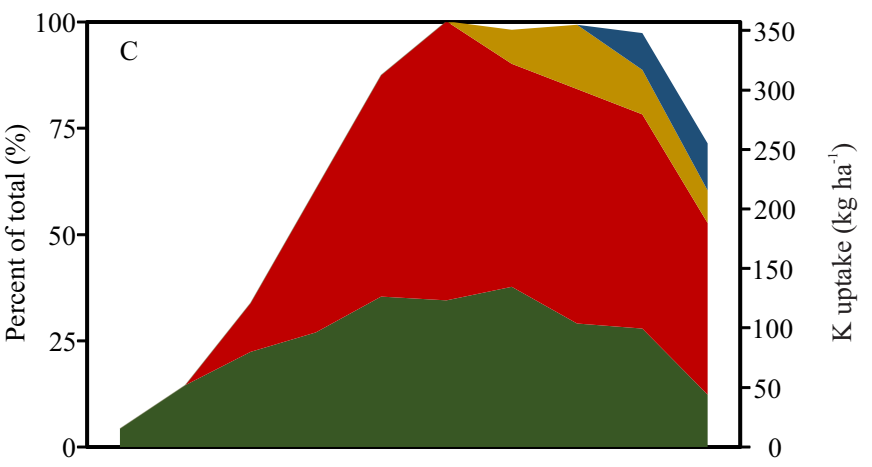

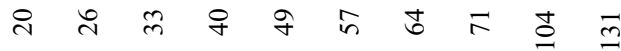

$$
\begin{aligned}
& \begin{array}{llllllllll}
\text { V4 } & \text { V5 } & \text { V7 } & \text { V9 } & \text { V12 } & \text { VT } & \text { R1 } & \text { R2 } & \text { R5 } & \text { R6 }
\end{array}
\end{aligned}
$$

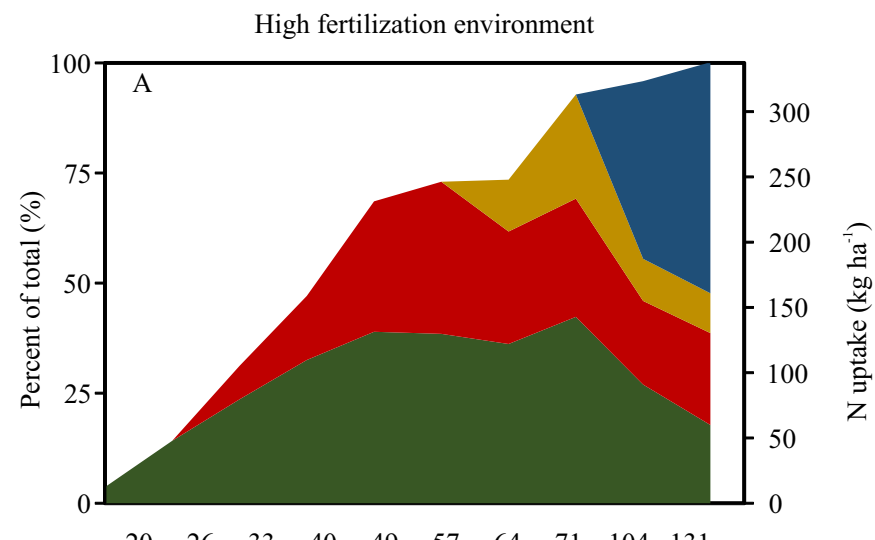

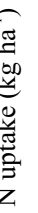

Figure 1. Equivalents of accumulation of $\mathrm{N}(\mathrm{A}), \mathrm{P}_{2} \mathrm{O}_{5}(\mathrm{~B})$, and $\mathrm{K}_{2} \mathrm{O}(\mathrm{C})$ in different compartments of the plant during the corn (Zea mays) cycle, in medium (left) and high (right) fertilization environments. Average of the four evaluated hybrids. DAS, days after sowing. 
The amount of $\mathrm{P}_{2} \mathrm{O}_{5}$ exported in both environments was, on average, $4.2 \mathrm{~kg}$ per megagram of grain (Table 3 and Figure 1), a value substantially lower than those compiled by Resende et al. (2012) from older Brazilian publications. Vasconcellos et al. (1983) and Bender et al. (2013) also found higher export ratios of $\mathrm{P}_{2} \mathrm{O}_{5}$, between $7.0-7.5 \mathrm{~kg} \mathrm{Mg}^{-1}$, than that of the present study. The extraction, productivity, and the export data reported here reflect efficiency gains in $\mathrm{P}$ use with the advances in crop breeding and in management systems in Brazil.

The equivalent quantity of $\mathrm{K}_{2} \mathrm{O}$ accumulated by hybrids was statistically different in the environments, in all evaluated seasons. In the high investment environment, plants accumulated a higher quantity of $\mathrm{K}_{2} \mathrm{O}$ from V5 onwards, with the greatest amount being stored in stalks, certainly due to the additional nutrient supply by fertilizers in this environment (Figure 1).

The uptake of total $\mathrm{K}$ by plants was more than $60 \%$ in V9, and the maximum accumulation occurred at tasseling (VT), at $57 \mathrm{DAS}$, in both the medium and high investment environments (Table 2 and Figure 1). Karlen et al. (1988) reported that the uptake of K was $86 \%$ until R1, whereas Von Pinho et al. (2009) identified that the maximum accumulation of the nutrient occurred at the final development stage, i.e., R6. Regardless of the cultivation environment and of the evaluated hybrid, the amount of K stored in the plant decreased after the R2 stage until the end of the cycle, in R6, when it remained about $60 \%$ of the maximum uptake (Table 2). This reduction is mainly due to the washing of nutrients by rain water or irrigation in the later stages of corn development, since $\mathrm{K}$ is not part of the plant structural components and is easily removed from tissues (Marschner, 2012).

At physiological maturation (R6), the average $\mathrm{K}$ contained in grains represented 26 and $11 \%$ total $\mathrm{K}$ uptake by corn plants grown in the medium and high fertilization environments, respectively (Table 3). This result is similar to the rates of 18 and $25 \%$ found by other authors in Brazil (Coelho \& França, 1995; Rossato, 2004). In tasseling (VT), corn plants accumulated the equivalent of 16.3 and $31.7 \mathrm{~kg}$ of $\mathrm{K}_{2} \mathrm{O}$ per each megagram of grains produced under medium and high investment, respectively. In R6, these values were 10.2 and $19.0 \mathrm{~kg}$. However, the higher $\mathrm{K}$ uptake in the most fertilized environment was not proportional to the export in grains, which was similar under medium and high investment -3.5 and $3.4 \mathrm{~kg} \mathrm{Mg}^{-1}$, respectively. It is worth noting that these export rates reflect a decreasing tendency compared with the values reported in previous works and compiled by Resende et al. (2012). Similarly to the observation regarding $\mathrm{P}$, the lower concentration of $\mathrm{K}$ in grains in the present study is an indicative that the development process of new cultivars has favored nutrient use efficiency in the corn crop.

A contrast was observed between $\mathrm{N}$ and $\mathrm{K}$ uptake patterns. Although the uptake of both nutrients increased with the increase of supply in the environment with greater investment, only the export of $\mathrm{N}$ showed a corresponding increase, differently from $\mathrm{K}$. This indicates that the reinforcement in $\mathrm{N}$ fertilization promotes the enrichment of grains with the nutrient, which does not occur for $\mathrm{K}$.

Ca uptake by corn was statistically different among environments only in the early development stages, i.e., V4, V7, and V9, when the environment with the

Table 3. Amount of $\mathrm{N}, \mathrm{P}_{2} \mathrm{O}_{5}$, and $\mathrm{K}_{2} \mathrm{O}$ exported in grains of transgenic corn (Zea mays) hybrids grown in medium and high fertilization environments ${ }^{(1)}$.

\begin{tabular}{|c|c|c|c|c|c|c|c|c|c|}
\hline \multirow[t]{2}{*}{ Hybrid } & \multicolumn{2}{|c|}{$\mathrm{N}\left(\mathrm{kg} \mathrm{ha}^{-1}\right)$} & \multirow{2}{*}{$\begin{array}{c}\text { Average by } \\
\text { hybrid }\end{array}$} & \multicolumn{2}{|c|}{$\mathrm{P}_{2} \mathrm{O}_{5}\left(\mathrm{~kg} \mathrm{ha}^{-1}\right)$} & \multirow{2}{*}{$\begin{array}{l}\text { Average by } \\
\text { hybrid }\end{array}$} & \multicolumn{2}{|c|}{$\mathrm{K}_{2} \mathrm{O}\left(\mathrm{kg} \mathrm{ha}^{-1}\right)$} & \multirow{2}{*}{$\begin{array}{c}\text { Average by } \\
\text { hybrid }\end{array}$} \\
\hline & Medium & High & & Medium & High & & Medium & High & \\
\hline AG 8088PROX & $132.1 \mathrm{a}$ & $162.8 \mathrm{a}$ & $147.5 b$ & $39.3 \mathrm{a}$ & $41.7 \mathrm{a}$ & $40.5 \mathrm{a}$ & $33.2 \mathrm{a}$ & $35.9 \mathrm{a}$ & $34.5 b$ \\
\hline DKB 310PRO2 & $154.3 \mathrm{a}$ & $219.0 \mathrm{a}$ & $186.7 \mathrm{a}$ & $47.7 \mathrm{a}$ & $54.9 \mathrm{a}$ & $51.3 \mathrm{a}$ & $44.3 \mathrm{a}$ & $48.3 \mathrm{a}$ & $46.3 \mathrm{a}$ \\
\hline DKB 390PRO & $140.3 \mathrm{a}$ & $169.8 \mathrm{a}$ & $155.1 \mathrm{~b}$ & $44.9 \mathrm{a}$ & $48.5 \mathrm{a}$ & $46.7 \mathrm{a}$ & $37.3 \mathrm{a}$ & $39.3 \mathrm{a}$ & $38.3 \mathrm{~b}$ \\
\hline P 30F53 YH & $107.3 \mathrm{a}$ & $156.0 \mathrm{a}$ & $131.6 \mathrm{~b}$ & $43.4 \mathrm{a}$ & $43.4 \mathrm{a}$ & $43.4 \mathrm{a}$ & $37.7 \mathrm{a}$ & $34.5 \mathrm{a}$ & $36.1 \mathrm{~b}$ \\
\hline $\begin{array}{l}\text { Environment } \\
\text { average }^{(2)}\end{array}$ & $\begin{array}{l}133.5 \mathrm{~B} \\
(54 \%)\end{array}$ & $\begin{array}{l}176.9 \mathrm{~A} \\
(52 \%)\end{array}$ & - & $\begin{array}{l}43.8 \mathrm{~A} \\
(74 \%)\end{array}$ & $\begin{array}{l}47.1 \mathrm{~A} \\
(69 \%)\end{array}$ & - & $\begin{array}{l}38.1 \mathrm{~A} \\
(26 \%)\end{array}$ & $\begin{array}{l}38.3 \mathrm{~A} \\
(11 \%)\end{array}$ & - \\
\hline CV (\%) & \multicolumn{2}{|c|}{15.5} & & \multicolumn{2}{|c|}{22.6} & \multicolumn{4}{|c|}{17.5} \\
\hline
\end{tabular}

${ }^{(1)}$ Means followed by equal letters, uppercase in the rows and lowercase in the columns, do not differ by the Scott-Knott test, at $5 \%$ probability. ${ }^{\left({ }^{2}\right)}$ Values inside parentheses correspond to the percentages exported in grains. CV, coefficient of variation. 
medium fertilization investment promoted greater nutrient accumulation. This result is consistent with the slightly higher $\mathrm{Ca}$ availability in the soil of this environment (Table 1). However, the high investment environment may also have restricted Ca uptake due to the higher availability of $\mathrm{K}$ in the soil (Table 1), which was further amplified by $\mathrm{K}$ topdressing in V5. The competitive inhibition among these cations is
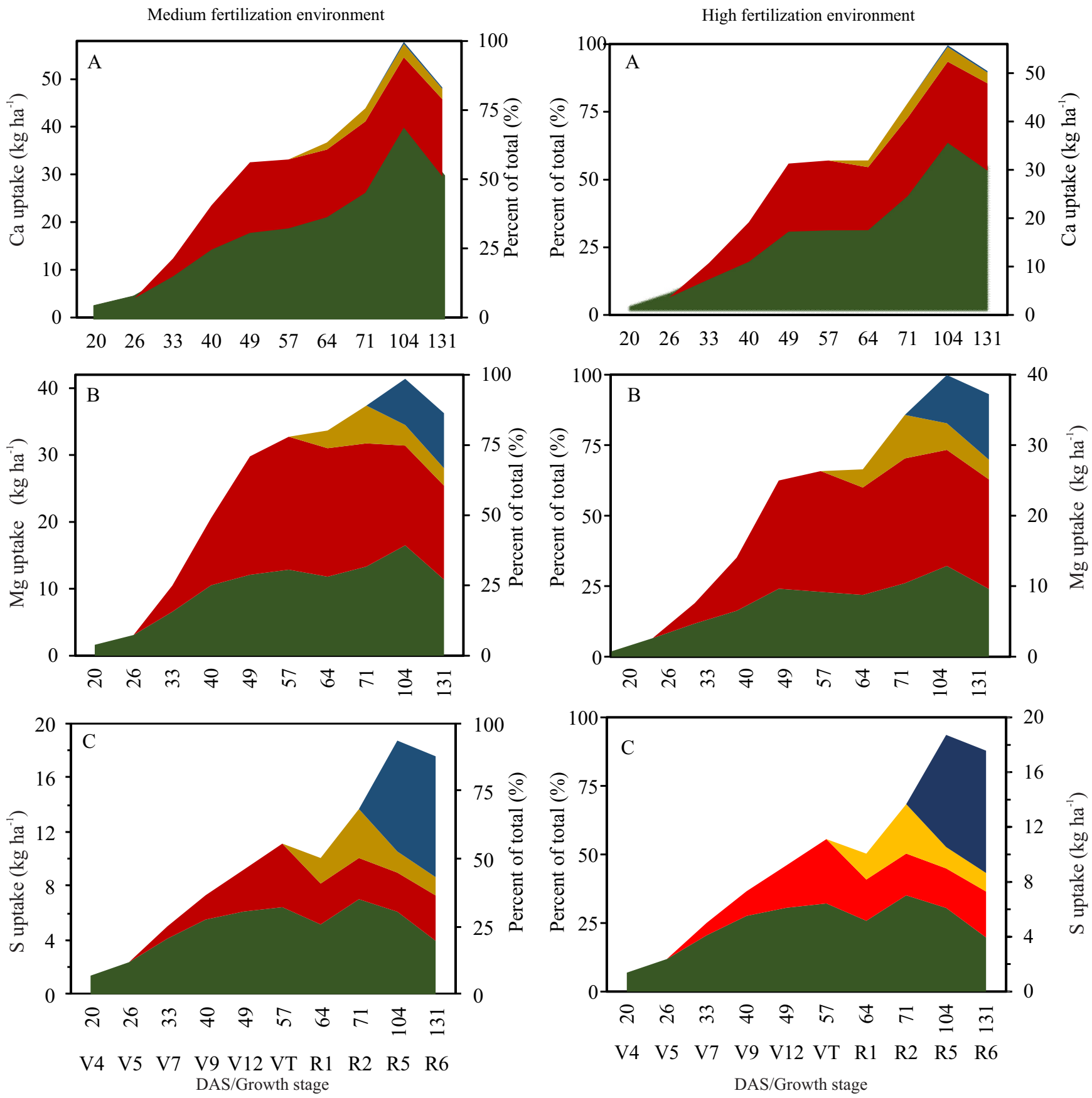

- Leaves $\quad$ Stalk and leaf sheaths $\quad$ Husk and cob Grain

Figure 2. Equivalents of accumulation of $\mathrm{Ca}(\mathrm{A}), \mathrm{Mg}(\mathrm{B})$, and $\mathrm{S}(\mathrm{C})$ in different compartments of the plant during the corn (Zea mays) cycle, in medium (left) and high (right) fertilization environments. Average of the four evaluated hybrids. DAS, days after sowing. 
well known (Malavolta et al., 1997), and it may have occurred in this study up to the V9 stage. About 57\% total $\mathrm{Ca}$ had already been accumulated by corn at tasseling, reaching $100 \%$ in R5 (Figure 2). The average maximum uptake was close to $57 \mathrm{~kg} \mathrm{ha}^{-1}$ (Table 2), corresponding to about $5.2 \mathrm{~kg}$ per each megagram of grain produced.

Ca was stored mainly in leaves (above 50\%) and in stalks (Figure 2). The allocation of this nutrient to the reproductive parts of the plant is minimal in the corn crop, representing only 3.0 to $10 \%$ total uptake (Coelho \& França, 1995; Vasconcellos et al., 1998). Therefore, $\mathrm{Ca}$ export to grains occurs in very small quantities as verified in the present study, where less than $1.0 \%$ was redistributed to grains, with an average export of only $0.3 \mathrm{~kg} \mathrm{ha}^{-1}$ (Table 4).

The accumulation of $\mathrm{Mg}$ was significantly higher under medium fertilization up to flowering in R1, but no differences were detected between environments after this stage. $\mathrm{Mg}$ uptake seems to have been markedly influenced by the high $\mathrm{K}$ availability in the environment with high investment in fertilization. However, the effects of both the $\mathrm{K}-\mathrm{Ca}$ and $\mathrm{K}-\mathrm{Mg}$ interactions were transient, disappearing as the corn cycle progressed, and apparently did not have a negative impact on the final $\mathrm{Ca}$ and $\mathrm{Mg}$ contents (Table 2) and on grain yield.

Until the tasseling stage (VT), the average Mg uptake was $79 \%$ of the total accumulated during the whole corn cycle in the medium investment environment, and $66 \%$ in the high investment one, reaching a maximum in R5, at 104 DAS (Figure 2). A similar behavior was observed by Von Pinho et al. (2009). However, Bender et al. (2013) identified maximum accumulation of $\mathrm{Mg}$ before flowering. Duarte et al. (2003) found a greater accumulation 77 to 95 days after emergence, while evaluating tropical climate cultivars in the municipality of Palmital, in the state of São Paulo, Brazil. Despite some variation in corn behavior under different study conditions, it is possible to conclude that most $\mathrm{Mg}$ uptake occurs at the pre-flowering stage, evidencing the importance of making this nutrient available in the initial development stages, up to R1.

Considering the average of the four evaluated hybrids, about 30\% total $\mathrm{Mg}$ uptake was directed to grains (Figure 2). This proportion is below the range between 36 and $69 \%$ reported by other authors (Vasconcellos et al., 1983; Coelho \& França 1995; Coelho \& Resende, 2008). In the present study, the average export of $\mathrm{Mg}$ in grains was between 8.2 and $9.3 \mathrm{~kg} \mathrm{ha}^{-1}$, in the medium and high investment environments, respectively (Table 4). For each megagram of produced grain, corn extracted $3.3 \mathrm{~kg}$ and exported $0.8 \mathrm{~kg}$.

The accumulation of $\mathrm{S}$ was significantly higher in the cultivation with high fertilization levels, for all evaluations performed from V5 onwards (Table 2). Uptake was favored by the higher quantity of S present in the soil (Table 1), mainly due to the application of phosphogypsum before the installation of the experiment, but also due to the use of ammonium sulfate in the third $\mathrm{N}$ topdressing fertilization in that environment. The maximum accumulation of $\mathrm{S}$ occurred in the R5-R6 stages, with $62 \%$, on average, of total uptake up to tasseling.

The export of $\mathrm{S}$ in grains was significantly higher in the high investment environment, with a $20 \%$ higher

Table 4. Amount of $\mathrm{Ca}, \mathrm{Mg}$, and $\mathrm{S}$ exported in grains of transgenic corn (Zea mays) hybrids grown in medium and high fertilization environments ${ }^{(1)}$.

\begin{tabular}{|c|c|c|c|c|c|c|c|c|c|}
\hline \multirow[t]{2}{*}{ Hybrid } & \multicolumn{2}{|c|}{$\mathrm{Ca}\left(\mathrm{kg} \mathrm{ha}^{-1}\right)$} & \multirow{2}{*}{$\begin{array}{c}\text { Average by } \\
\text { hybrid }\end{array}$} & \multicolumn{2}{|c|}{$\operatorname{Mg}\left(\mathrm{kg} \mathrm{ha}^{-1}\right)$} & \multirow{2}{*}{$\begin{array}{c}\text { Average by } \\
\text { hybrid }\end{array}$} & \multicolumn{2}{|c|}{$\mathrm{S}\left(\mathrm{kg} \mathrm{ha}^{-1}\right)$} & \multirow{2}{*}{$\begin{array}{c}\text { Average by } \\
\text { hybrid }\end{array}$} \\
\hline & Medium & High & & Medium & High & & Medium & High & \\
\hline AG 8088PROX & $0.27 \mathrm{a}$ & $0.32 \mathrm{a}$ & $0.29 \mathrm{a}$ & $7.3 \mathrm{a}$ & $8.2 \mathrm{a}$ & $7.8 \mathrm{~b}$ & $8.3 \mathrm{a}$ & $10.1 \mathrm{a}$ & $9.2 \mathrm{~b}$ \\
\hline DKB 310PRO2 & $0.28 \mathrm{a}$ & $0.35 \mathrm{a}$ & $0.32 \mathrm{a}$ & $9.5 \mathrm{a}$ & $11.3 \mathrm{a}$ & $10.4 \mathrm{a}$ & $10.2 \mathrm{a}$ & $13.3 \mathrm{a}$ & $11.8 \mathrm{a}$ \\
\hline DKB 390PRO & $0.39 \mathrm{a}$ & $0.41 \mathrm{a}$ & $0.40 \mathrm{a}$ & $8.9 \mathrm{a}$ & $9.3 \mathrm{a}$ & $9.1 \mathrm{a}$ & $8.8 \mathrm{a}$ & $10.1 \mathrm{a}$ & $9.5 \mathrm{~b}$ \\
\hline P 30F53 YH & $0.27 \mathrm{a}$ & $0.17 \mathrm{a}$ & $0.22 \mathrm{a}$ & $7.29 \mathrm{a}$ & $8.4 \mathrm{a}$ & $7.8 \mathrm{~b}$ & $8.4 \mathrm{a}$ & $9.4 \mathrm{a}$ & $8.9 \mathrm{~b}$ \\
\hline $\begin{array}{l}\text { Environment } \\
\text { average }^{(2)}\end{array}$ & $\begin{array}{l}0.30 \mathrm{~A} \\
(0.6 \%)\end{array}$ & $\begin{array}{l}0.31 \mathrm{~A} \\
(0.6 \%)\end{array}$ & - & $\begin{array}{c}8.2 \mathrm{~A} \\
(23 \%)\end{array}$ & $\begin{array}{c}9.3 \mathrm{~A} \\
(25 \%)\end{array}$ & - & $\begin{array}{c}8.9 \mathrm{~B} \\
(51 \%)\end{array}$ & $\begin{array}{l}10.7 \mathrm{~A} \\
(47 \%)\end{array}$ & - \\
\hline CV $(\%)$ & \multicolumn{2}{|c|}{52.6} & & \multicolumn{2}{|c|}{19.9} & \multicolumn{4}{|c|}{17.5} \\
\hline
\end{tabular}


nutrient removal than that observed under the medium investment (Table 4 and Figure 2). However, despite the contrasting amount of $\mathrm{S}$ uptake between the environments, the yield-weighted responses of corn tended to be leveled, with extraction ranging from 1.6 to $2.0 \mathrm{~kg} \mathrm{ha}^{-1}$ and export from 0.8 to $0.9 \mathrm{~kg} \mathrm{Mg}^{-1}$. These values are below the interval of $2.5-4.0 \mathrm{~kg} \mathrm{ha}^{-1}$ and $1.0-2.0 \mathrm{~kg} \mathrm{Mg}^{-1}$ reported by Sousa \& Lobato (2004).

There was no significant interaction between hybrids and fertilization investment; however, statistically significant differences were observed in nutrient accumulation among hybrids, especially in the reproductive stage, with emphasis on DKB 310PRO2, which showed the highest macronutrient contents at physiological maturation, except for $\mathrm{P}$ and $\mathrm{K}$. The DKB 310PRO2 and P 30F53 YH hybrids accumulated higher quantities of $\mathrm{K}$ at physiological maturation, which is partially due to the morphological characteristics of these materials, since $\mathrm{K}$ is accumulated in larger quantities in stalks. The TDM production of DKB 310PRO2 was $32,059 \mathrm{~kg} \mathrm{ha}^{-1}$, much higher than that of the other hybrids, which did not differ significantly between themselves: AG 8088PROX, with 23,555 kg $\mathrm{ha}^{-1}$; DKB 390PRO, with $23,429 \mathrm{~kg} \mathrm{ha}^{-1}$; and P 30F53 $\mathrm{YH}$, with $23,465 \mathrm{~kg} \mathrm{ha}^{-1}$. Moreover, considering the stalk compartment alone, the difference was over $1,000 \mathrm{~kg} \mathrm{ha}^{-1}$ dry matter for DKB 310PRO2, which developed larger stalks.

The concentrations of $\mathrm{P}, \mathrm{K}$, and $\mathrm{S}$ in grains were lower than those reported in the literature. The obtained results emphasize the importance of updating the data on corn requirements, aiming to update fertilization standards based on the replacement of nutrients removed from fields, which can improve nutritional management recommendations for the crop.

\section{Conclusions}

1. Increases in dry matter mass production related to environments with greater fertilization investments do not necessarily result in increased grain yield of transgenic corn (Zea mays) hybrids.

2. Nutrient uptake differences between the evaluated transgenic corn hybrids are mainly due to variations in biomass accumulation.

3. Expressive later uptake of $\mathrm{N}, \mathrm{P}, \mathrm{Ca}, \mathrm{Mg}$, and $\mathrm{S}$, as well as lower concentrations of $\mathrm{P}, \mathrm{K}$, and $\mathrm{S}$ in grains, make the studied modern transgenic corn hybrids stand out compared with the older ones, and indicate opportunities for updating and improving nutritional management recommendations for the crop.

\section{Acknowledgments}

To Embrapa Milho e Sorgo, for financial support and for the use of their experimental station; to Fundação de Amparo à Pesquisa do Estado de Minas Gerais (Fapemig), for grants; and to Coordenação de Aperfeiçoamento de Pessoal de Nível Superior (Capes), for grant to the first author.

\section{References}

ALVES, V.M.C.; VASCONCELLOS, C.A.; FREIRE, F.M.; PITTA, G.V.E.; FRANÇA, G.E.; RODRIGUES FILHO, A.; ARAÚJO, J.M.; VIEIRA, J.R.; LOUREIRO, J.E. Milho. In: RIBEIRO, A.C.; GUIMARAES, P.T.G., ALVAREZ V., V.H. (Ed.). Recomendações para o uso de corretivos e fertilizantes em Minas Gerais: 5a Aproximação. Viçosa: Comissão de Fertilidade do Solo do Estado de Minas Gerais, 1999. p.314-316.

BENDER, R.R.; HAEGELE, J.W.; RUFFO, M.L.; BELOW, F.E. Nutrient uptake, partitioning, and remobilization in modern, transgenic insect-protected maize hybrids. Agronomy Journal, v.105, p.161-170, 2013. DOI: 10.2134/agronj2012.0352.

COELHO, A.M.; FRANÇA, G.D. de. Seja o doutor do seu milho: nutrição e adubação. Piracicaba: Potafos, 1995. (Arquivo do Agrônomo, $\mathrm{n}^{\circ}$ 2).

COELHO, A.M.; RESENDE A.V. de R. Exigências nutricionais e adubação do milho safrinha. Sete Lagoas: Embrapa Milho e Sorgo, 2008. 10p. (Embrapa Milho e Sorgo. Circular técnica, 111).

DUARTE, A.P.; KIEHL, J. de C.; CAMARGO, M.A.F. de; RECO, P.C. Acúmulo de matéria seca e nutrientes em cultivares de milho originárias de clima tropical e introduzidas de clima temperado. Revista Brasileira de Milho e Sorgo, v.2, p.1-20, 2003. DOI: 10.18512/1980-6477/rbms.v2n3p1-20.

FERREIRA, D.F. Sisvar: a computer statistical analysis system. Ciência e Agrotecnologia, v.35, p.1039-1042, 2011. DOI: 10.1590/ S1413-70542011000600001.

FONTOURA, S.M.V.; BAYER, C. Adubação nitrogenada para alto rendimento de milho em plantio direto na região centro-sul do Paraná. Revista Brasileira de Ciência do Solo, v.33, p.17211732, 2009. DOI: 10.1590/S0100-06832009000600021.

FREITAS, R.S. de; DUARTE, A.P.; LEÃO, P.C. da L.; KASAI, F.; CAZENTINI FILHO, G.; TICELII, M.; MINGOTTE, F.L.C.; PESSINATTI, F.A.; FORNASIERI FILHO, D.; BORGES, W. L.B.; VITOR, L.G.; OLIVEIRA, A.L. de; PONTE, M.S. Produtividade de grãos em cultivares de milho transgênicas na região o Norte/Oeste do Estado de São Paulo em 2011/12 e 2012/13. Nucleus, v.10, p.125-134, 2013. Edição especial. DOI: 10.3738/nucleus.v0i0.916. 
FURLANI, P.R.; HIROCE, R.; BATAGLIA, O.C.; SILVA, W.J. Acúmulo de macronutrientes, de silício e de matéria seca por dois híbridos simples de milho. Bragantia, v.36, p.223-229, 1977. DOI: 10.1590/S0006-87051977000100022.

KARLEN, D.L.; FLANNERY, R.L.; SADLER, E.J. Aerial accumulation and partitioning of nutrients by corn. Agronomy Journal, v.80, p.232-242, 1988. DOI: 10.2134/agronj1988.000219 62008000020018x.

MALAVOLTA, E.; VITTI, G.C.; OLIVEIRA, S.A. de. Avaliação do estado nutricional das plantas: princípios e aplicações. 2.ed. Piracicaba: Associação Brasileira para a Pesquisa da Potassa e do Fosfato, 1997. 319p.

MARSCHNER, H. (Ed.). Marschner's mineral nutrition of higher plants. $3^{\text {rd }}$ ed. London: Academic Press, 2012. DOI: 10.1016/C2009-0-63043-9.

PADILHA, F.A.; RESENDE, A.V. de; MOREIRA, S.G.; GUIMARÃES, L.J.M.; GUIMARÃES, P.E.O; OLIVEIRA, A.C. de. Produtividade de híbridos de milho sob dois níveis de tecnologia na região central de Minas Gerais. Revista Brasileira de Milho e Sorgo, v.14, p.207-218, 2015. DOI: 10.18512/19806477/rbms.v14n2p207-218.

RAIJ, B. van.; CANTARELLA, H.; QUAGGIO, J.A. FURLANI, A.M.C. (Ed.). Recomendações de adubação e calagem para o Estado de São Paulo. 2.ed. Campinas: Instituto Agronômico, 1997. 285p. (IAC. Boletim técnico, 100).

RESENDE, A.V. de; COELHO, A.M.; SANTOS, F.C. dos; LACERDA, J.J. de J. Fertilidade do solo e manejo da adubação NPK para alta produtividade de milho no Brasil Central. Sete Lagoas: Embrapa Milho e Sorgo, 2012. 12p. (Embrapa Milho e Sorgo. Circular técnica, 181).

RITCHIE, S.W.; HANWAY, J.J.; BENSON, G.O. Como a planta de milho se desenvolve. Informações Agronômicas, n.103, p.119, 2003.

ROSSATO, R.R. Potencial de ciclagem de nitrogênio e potássio pelo nabo forrageiro intercalar ao cultivo do milho e trigo sob plantio direto. 2004. 130p. Dissertação (Mestrado) Universidade Federal de Santa Maria, Santa Maria.

SANTOS, H.G. dos; JACOMINE, P.K.T.; ANJOS, L.H.C. dos; OLIVEIRA, V.A. de; LUMBRERAS, J.F.; COELHO, M.R.; ALMEIDA, J.A. de; CUNHA, T.J.F.; OLIVEIRA, J.B. de. Sistema brasileiro de classificação de solos. 3.ed. rev. e ampl. Brasília: Embrapa, 2013. 353p.

SILVA, C.G.M. Absorção e exportação de macronutrientes em milho transgênico sob dois níveis de investimento em adubação. 2016. 49p. Dissertação (Mestrado) - Universidade Federal de São João Del Rei, Sete Lagoas.

SILVA, F.C. da (Ed.). Manual de análises químicas de solos, plantas e fertilizantes. 2.ed. rev. e ampl. Brasília: Embrapa Informação Tecnológica, 2009. 627p.

SOUSA, D.M.G. de; LOBATO, E. Calagem e adubação para culturas anuais e semiperenes. In: SOUSA, D.M.G. de; LOBATO, E. (Ed.). Cerrado: correção do solo e adubação. 2.ed. Planaltina: Embrapa Cerrados, 2004. p.283-313.

VASCONCELLOS, C.A.; BARBOSA, J.V.A.; SANTOS, H.L. dos; FRANÇA, G.E. de. Acumulação de massa seca e de nutrientes por duas cultivares de milho com e sem irrigação suplementar. Pesquisa Agropecuária Brasileira, v.18, p.887-901, 1983.

VASCONCELLOS, C.A.; VIANA, M.C.M.; FERREIRA, J.J. Acúmulo de matéria seca e de nutrientes em milho cultivado no período inverno-primavera. Pesquisa Agropecuária Brasileira, v.33, p.1835-1845, 1998 .

VILAR, C.C.; VILAR, F.C.M. Comportamento do fósforo em solo e planta. Campo Digital: Revista Ciências Exatas e da Terra e Ciências Agrárias, v.8, p.37-44, 2013.

VON PINHO, R.G.; BORGES, I.D.; PEREIRA, J.L. de A.R.; REIS, M.C. dos Marcha de absorção de macronutrientes e acúmulo de matéria seca em milho. Revista Brasileira de Milho e Sorgo, v.8, p.157-173, 2009. DOI: 10.18512/1980-6477/ rbms.v8n2p157-173.

Received on May 5, 2017 and accepted on April 19, 2018

Pesq. agropec. bras., Brasília, v.53, n.12, p.1363-1372, Dec. 2018

DOI: 10.1590/S0100-204X2018001200009 